\title{
ASSESSMENT OF THE VISIBILITY CAPABILITIES OF FOREST FIRE LOOKOUT TOWERS: THE CASE OF GEMLIK, BURSA, TURKEY
}

\author{
A. E. Akay* \\ Bursa Technical University, Faculty of Forestry, 16310 Yıldırım, Bursa, Turkey - abdullah.akay@btu.edu.tr*
}

Commission VI, WG VI/4

KEY WORDS: Forest Fires, Fire Detection, Fire Lookout Towers, GIS, Visibility Analysis, Bursa.

\begin{abstract}
:
In Turkey, there are forest areas that are sensitive to fire in the first degree, especially along the coastline in the Marmara region and the Aegean and Mediterranean regions. As a result of forest fires, which is one of the biggest environmental disasters on forest resources, approximately 10000 hectares of forest area is damaged annually. One of the important elements of combating forest fires is early detection. In order to achieve this goal, the correct positioning of fire lookout towers is of great importance. In this study, it was aimed to evaluate visibility capabilities of forest fire lookout tower in Gemlik Forestry Enterprise Chief (FEC) located in the city of Bursa. Firstly, the visibility analysis was implemented using in ArcGIS 10.4.1 to evaluate the existing fire tower in the FEC, and then considering the potential fire lookout tower in the study area, the visible areas from both existing and new tower were determined. According to the results, while $63.55 \%$ of the study area was visible from the existing tower, this ratio increased to $77.39 \%$ when the second tower was added. When only the forest areas are evaluated, the existing tower could see $71.73 \%$ of the forest areas, while the visible forest areas have increased to $83.36 \%$ when the two towers were taken into account. It has been seen that the visibility capacities of existing towers and potential towers can be evaluated effectively by using GIS-based visibility analysis.
\end{abstract}

\section{INTRODUCTION}

Combustion is a chemical oxidation that occurs at high temperatures and releases stored heat energy through photosynthesis. Combustion occurs when the ignition temperature, oxygen and combustible material come together in sufficient quantities. Forest fires are fires that partially or completely burn all living and non-living combustible materials in forest areas and tend to spread freely due to the open environment (Eroğlu, 2009).

Forest fires are divided into three types. Soil fire occurs in the forest with the reflection of thick layers of organic matter on the mineral soil, in other words, under the soil surface. This fire mainly proceeds underground; sometimes it rises above the ground and causes a surface fire. This type of fire is very difficult to fight. The second type of fire is the surface fire, and it is the fire that burns the dead and living surface material that covers the soil. This is the most common type of fire in any type of forest.

Among the fire types, the most dangerous and fastest growing is the crown fire. This fire progresses at different intensity and speed depending on the type of dead and living cover. It is a fire that proceeds by burning the tops of trees and shrubs separated from the surface fire. This type of fire usually occurs as a result of the surface fire passing to the canopy of the tree and shrubs (Çanakçığlu, 1993).

In order to be able to fight forest fires effectively, it is necessary to respond to the fire as soon as possible. For this reason, it is of great importance to detect and locate forest fires as soon as they start, and to notify the firefighting team without delay (Çanakçıŏlu, 1993). In order to detect fires early, fire lookout towers are built to monitor forests and provide communication, especially in areas sensitive to fires. Fire surveillance workers working in these towers during the fire season watch the forest areas with binoculars 24 hours a day.

Fire lookout towers should be set up on high hills relative to their surroundings, allowing the surveillance of a large part of the forested areas in the region. Geographic Information Systems (GIS) seem to have significant potential in the effective implementation of all kinds of planning in the fight against forest fires (Erten et al., 2005). The locations of fire towers can be evaluated in the GIS environment by using the visibility analysis method.

Korkmaz (2004) determined alternative observation points for fire lookout towers and determined the areas that can be observed from these points. As a result of the study, it was determined that four towers were able to fulfil the surveillance function adequately in terms of their current positions, while the current position of one tower was not included in the optimum solution. In addition, it was understood that new lookout towers should be built at two points.

Akay et al. (2012) evaluated fire lookout towers using visibility analysis from GIS techniques. Four fire lookout towers in the study area were taken into account. The forest areas that can be seen by the towers were determined and the locations of the towers were evaluated. As a result of the study, it was found that approximately $37 \%$ of the forest areas can be seen by the existing towers.

In this study, GIS based visibility analysis was used to determine visible and nonvisible forest areas from a fire lookout tower currently located in the study area. Then, the capability of new fire lookout tower was evaluated using visibility analysis in ArcGIS 10.4.1. 


\section{MATERIAL AND METHODS}

\subsection{Study Area}

The study area was Gemlik Forest Enterprise Chief (FEC) within the city of Bursa in Turkey (Figure 1). The average elevation and ground slope was $457.96 \mathrm{~m}$ and $32.73 \%$, respectively. The dominant trees in the study area were Beech, Black Pine, and Oak.

\subsection{GIS Database}

2.2.1 Forest Cover Map: The forest management map obtained from the Gemlik FEC was used to produce land use type map based on the basis of stand subdivision. Then, using the "Reclassify" feature in ArcGIS 10.4.1, the land use types in the study area were grouped under five classes (Figure 2). Finally, the forest cover map was extracted from the reclassified land use type map of the study area.

2.2.2 DEM: The success of visibility analysis depends on the Digital Elevation Model (DEM). In this study, DEM was generated using the contour map (1:25000) with $10 \mathrm{~m}$ intervals (Figure 3). The contour map was obtained from the Gemlik FEC.

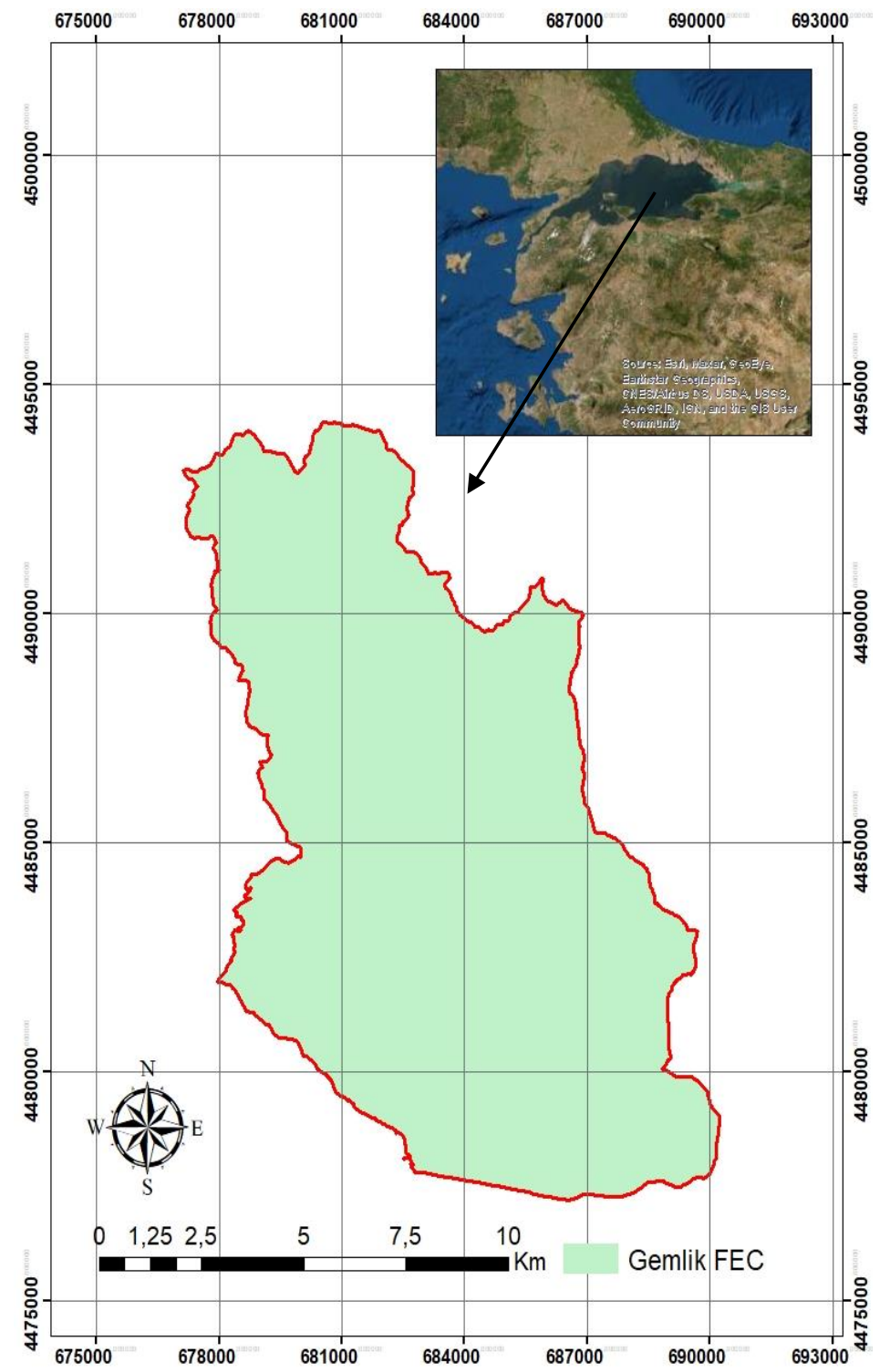

Figure 1. Study area. 


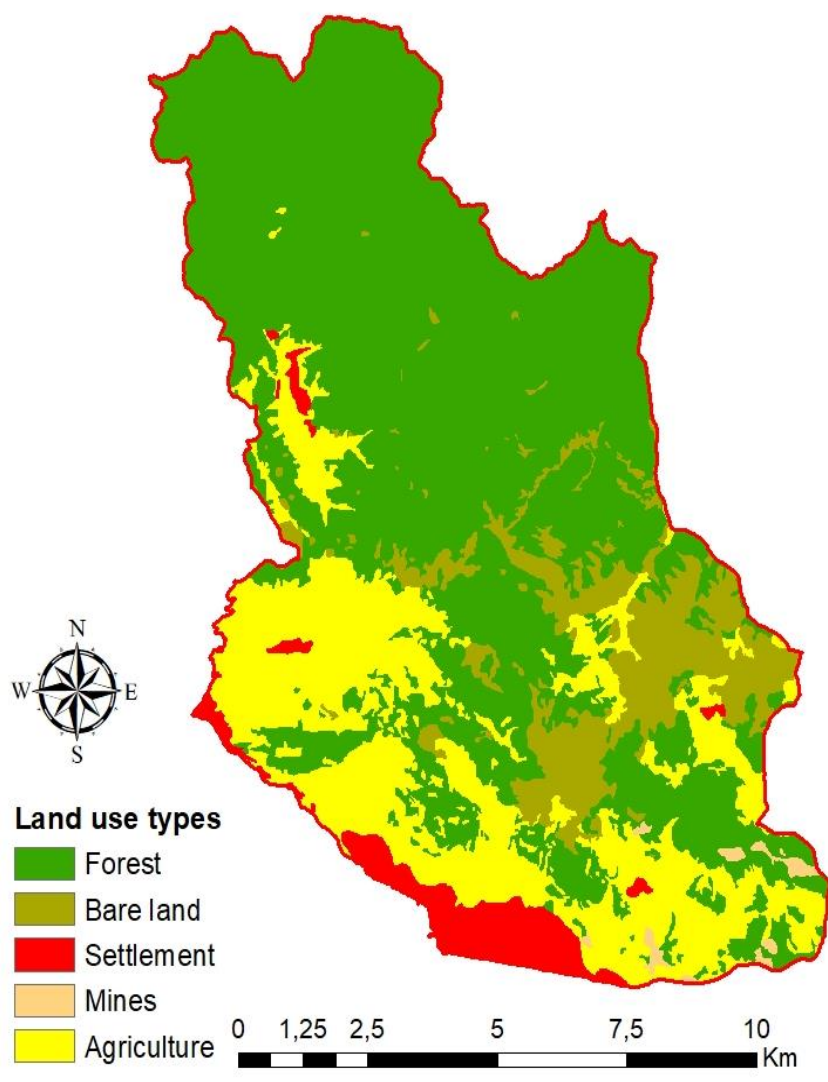

Figure 2. Land use type map.

\subsection{Visibility Analysis}

Visibility analysis was performed using the "Observer Points" feature in ArcGIS 10.4.1. For this purpose, data fields required for visibility analysis were added to the attribute table of the data layer showing the locations of the existing fire lookout tower. In this study, the viewing angle was considered as 360 degrees in order to scan the entire working area from the tower. Visibility height (Smoke Visibility) was determined as $100 \mathrm{~m}$ in order to be able to see not only the flames directly on the ground but also the smoke rising from the ground during the fire. Vertical viewing angles were entered as +90 degrees and 90 degrees. Visibility distances and other information on fire towers are shown in Table 1.

\begin{tabular}{|c|c|c|c|c|c|}
\hline $\begin{array}{c}\text { Altitude } \\
(\mathrm{m})\end{array}$ & $\begin{array}{c}\text { Tower } \\
\text { Height } \\
(\mathrm{m})\end{array}$ & $\begin{array}{c}\text { Smoke } \\
\text { Height } \\
(\mathrm{m})\end{array}$ & $\begin{array}{c}\text { Horizontal } \\
\text { Visibility } \\
\text { Angle (degree) }\end{array}$ & $\begin{array}{c}\text { Visibility } \\
\text { Range } \\
(\mathrm{m})\end{array}$ & $\begin{array}{c}\text { Vertical } \\
\text { Visibility } \\
\text { Angle } \\
(\text { degree })\end{array}$ \\
\hline 855 & 6 & 100 & 360 & 25000 & $+/-90$ \\
\hline
\end{tabular}

Table 1. The field data of watch tower layer.

In the second stage, the visible areas from the potential fire lookout tower in the study area was determined. Then, the visible and nonvisible areas from both lookout towers were indicated for Gemlik FEC. Then, the map of forested areas was used to evaluate visibility of forested areas.

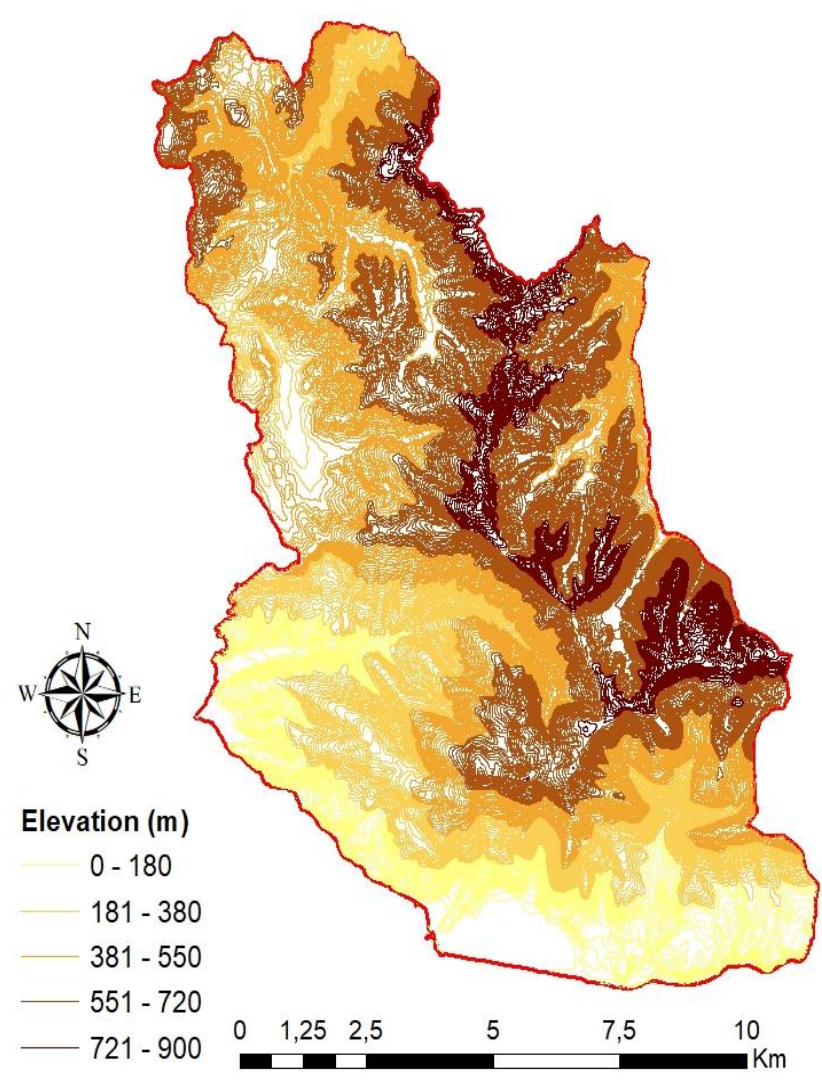

Figure 3. Contour lines.

\section{RESULTS AND DISCUSSION}

The land use types (forest, bare land, settlements, mine, agriculture) in the study area were classified in the ArcGIS 10.4.1 environment. The land use type with the largest area in the study areas was forest (61\%), followed by agriculture (23.98\%) (Table 2). Then, a data layer showing forest area was produced. Figure 4 indicates the forest cover in the study area. Then, DEM was generated based on the contour map of the study area (Figure 5).

\begin{tabular}{|l|c|}
\hline Land use types & Area (\%) \\
\hline Forest & 61.00 \\
Bare land & 10.54 \\
Settlements & 3.91 \\
Mine & 0.57 \\
Agriculture & 23.98 \\
\hline
\end{tabular}

Table 2. The areal distribution of land use types

According to the results of the visibility analysis, the areas observed by the existing fire tower is shown in Figure 6. It was found that $63.55 \%$ of the total area was visible from the existing tower. In a similar study conducted by Akay and Erdoğan (2017), it was reported that $79 \%$ of the whole Yayla FEC located in the city of Balıkesir in Turkey was visible from the lookout towers. 


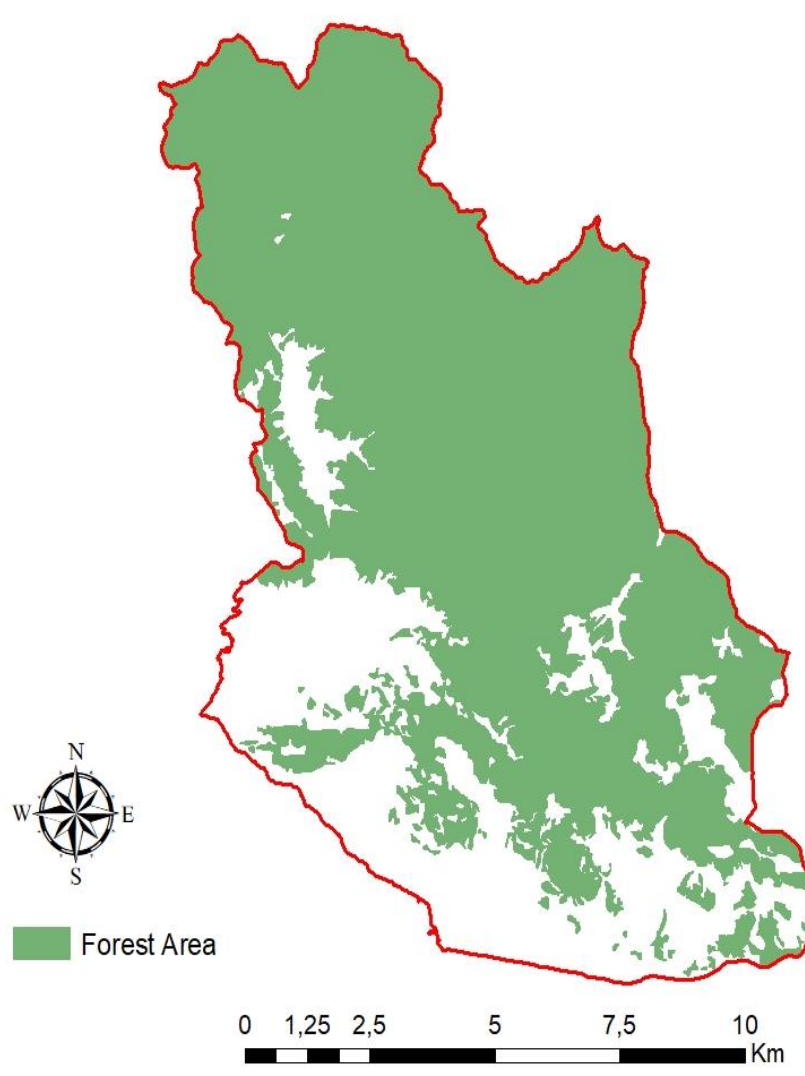

Figure 4. Forest area.

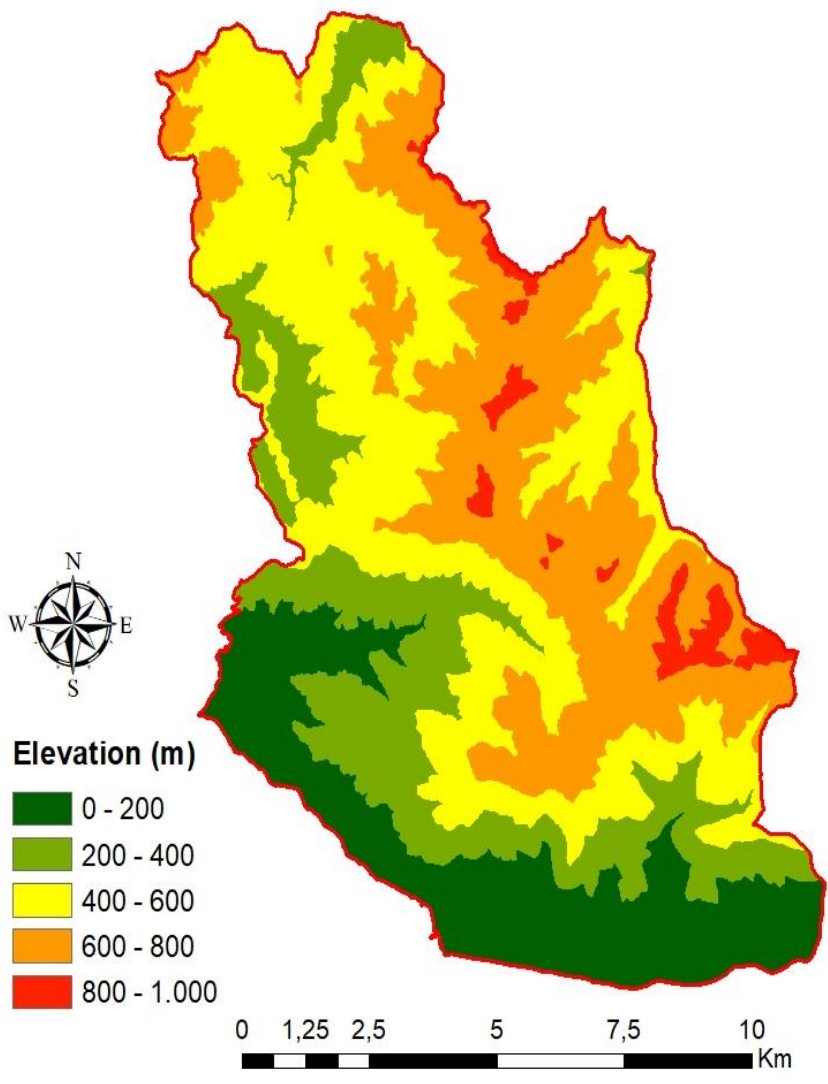

Figure 5. DEM of the study area.

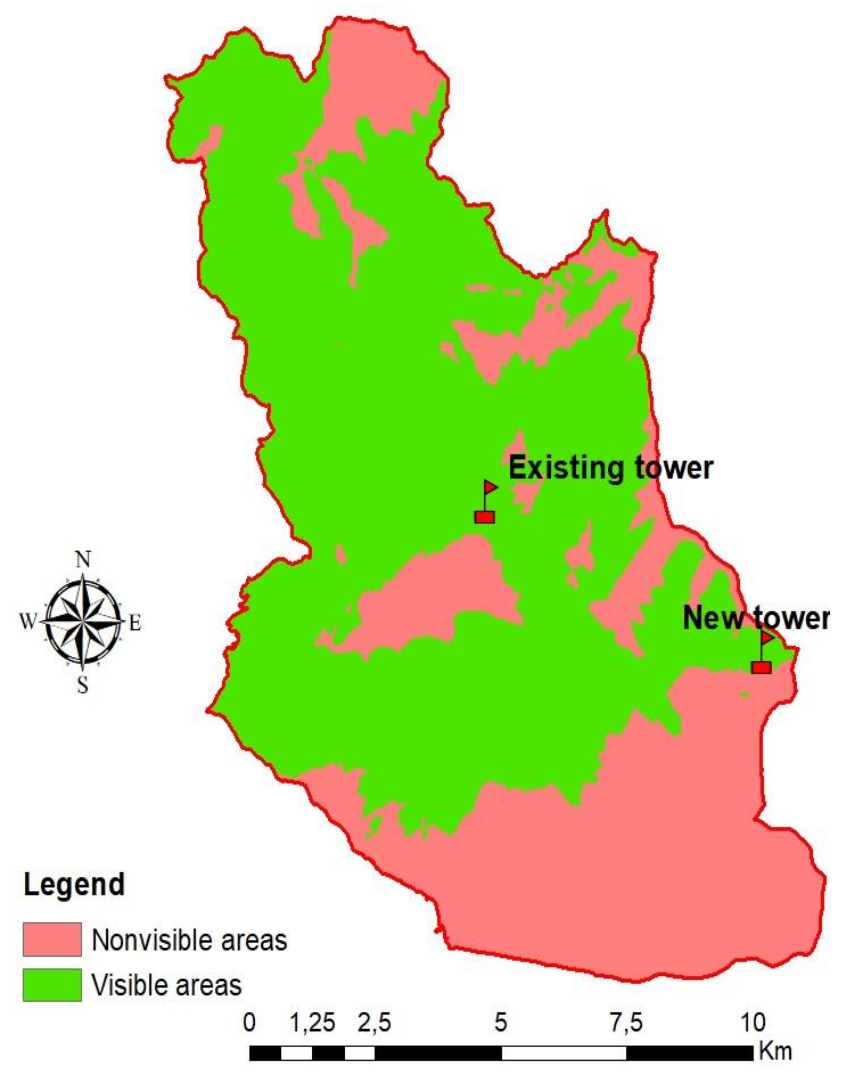

Figure 6. Visible areas from the existing tower. 
When considering the potential new fire lookout tower in the study area, the visible areas from both existing and new tower increased to $77.39 \%$. Thus, installing new lookout tower provided additional $13.84 \%$ of visible area in the study area (Figure 7).

In the case of forest areas, $71.73 \%$ of the forest area was within the sight of the existing tower. On the other hand, visible forest areas increased up to $83.36 \%$ considering the new tower (Figure 8 ). Therefore, $11.63 \%$ of additional visible forest area was provided after installing the new tower. It was also found that $19.62 \%$ of the forest are was visible from two towers. Table 3 indicates the visible areas from the fire lookout towers.

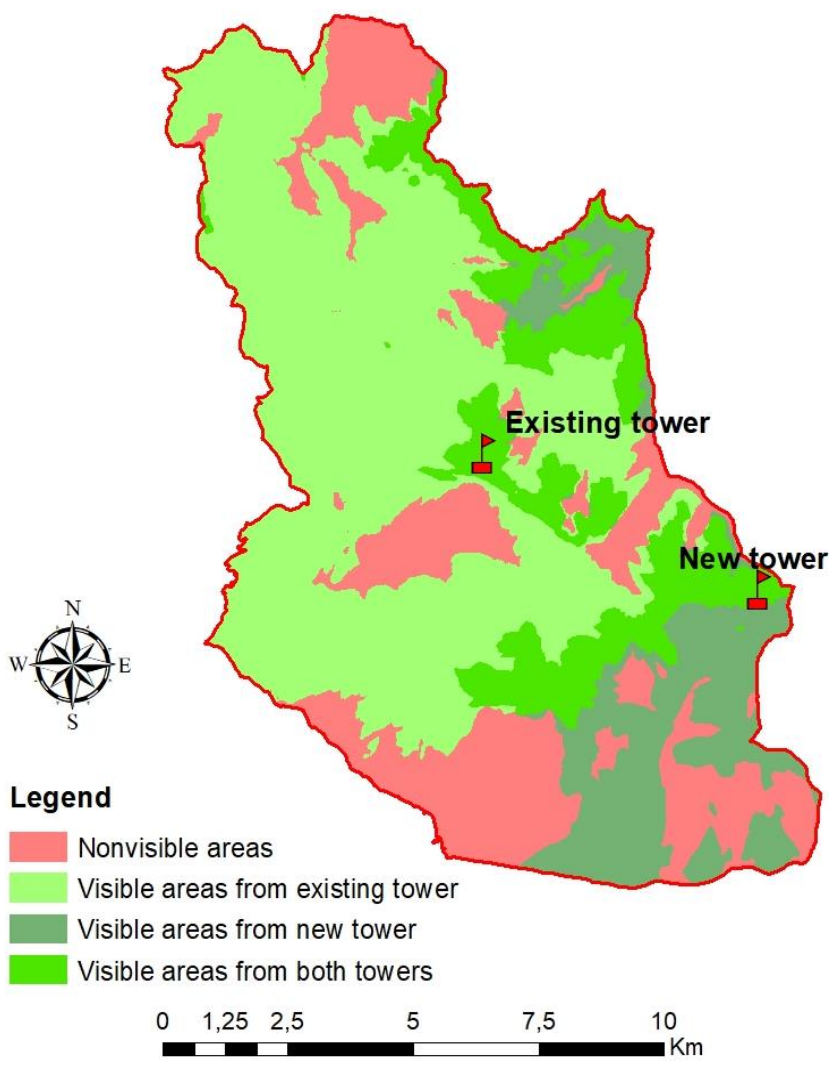

Figure 7. Visible areas from both towers.

\section{CONCLUSIONS}

In this study, GIS-based visibility analysis was used in order to determine the forest areas that can be seen from the forest fire lookout towers. Within the scope of the study, Gemlik FEC, which is located in the city of Bursa in Turkey, was considered. In the solution process, capabilities of existing tower and potential new tower was evaluated. It was found that $63.55 \%$ of the study area was visible from the existing tower, while it was $77.39 \%$ considering the new tower. On the other hand, $71.73 \%$ of the forest areas was visible from the existing tower, while it was $83.36 \%$ when new tower was taken into account. It can be concluded that new tower should be placed in the study area or the location of existing towers should be re-evaluated.

\begin{tabular}{|c|c|c|}
\hline $\begin{array}{c}\text { Number of } \\
\text { Observing Towers }\end{array}$ & Towers & Area (\%) \\
\hline- & Nonvisible & 22.6 \\
1 & Existing tower & 49.0 \\
1 & New tower & 13.8 \\
2 & Both towers & 14.6 \\
\hline Total & & 100.00 \\
\hline
\end{tabular}

Table 3. The forest areas from the fire lookout towers.

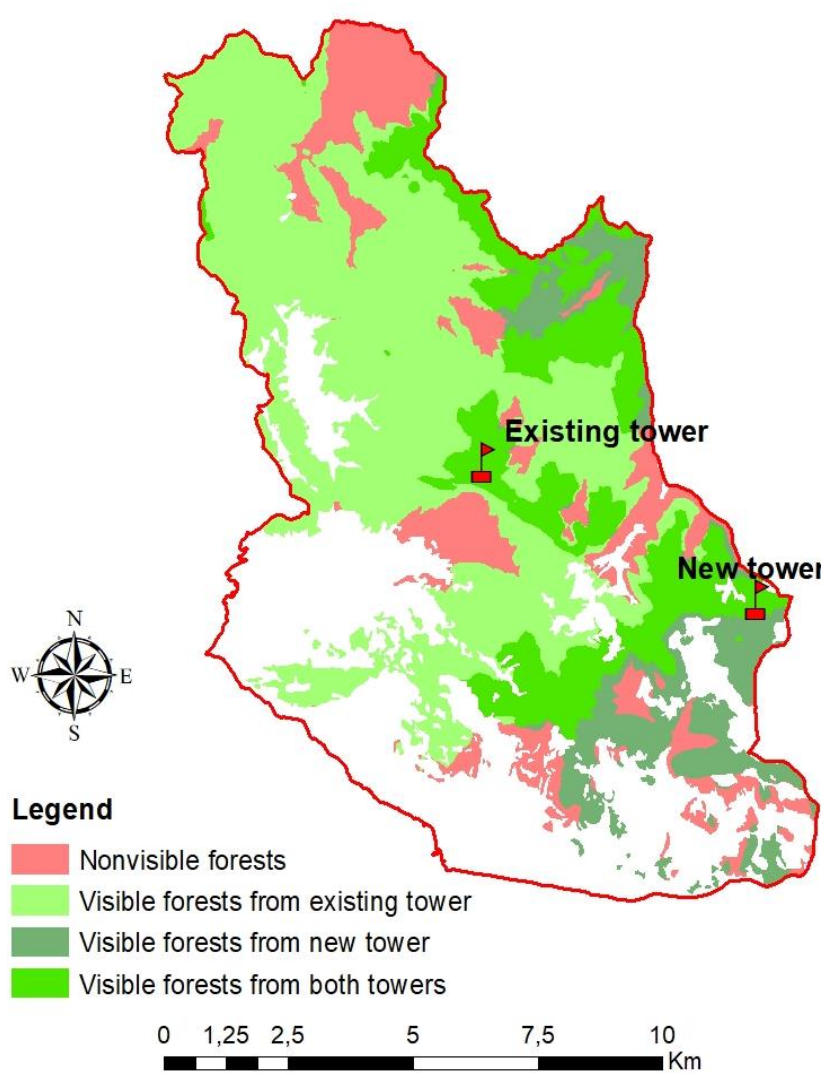

Figure 8. Visible forests from both towers.

\section{REFERENCES}

Akay, A.E., Wing, G.M., Sivrikaya, F., Sakar, D., 2012: A GISbased decision support system for determining the shortest and safest route to forest fires: a case study in Mediterranean Region of Turkey. Environmental Monitoring and Assessment, 184(3), 1391-1407.

Akay, A.E., Erdoğan, A. 2017: Assessment of Fire Watch Towers by using Visibility Analysis: The Case of Dursunbey, Balıkesir. ISFOR 2017 International Symposium on New Horizons in Forestry, 18-20 October, Isparta, Turkey.

Çanakçıŏlu, H., 1993: Forest Protection. İstanbul: İstanbul University Publication. 
Erten, E., Kurgun, V., Musaoglu, N., 2004: Forest Fire Risk Zone Mapping from Satellite Imagery and GIS a Case Study. XXth ISPRS Congress, Youth Forum, Editor(s): Orhan Altan, July 12-23, Istanbul, Turkey. pp. 33-39.

Ertuğrul, M., 2005: The Situation of Forest Fires in the World and in Turkey. ZKÜ Bartın Faculty of Forestry Journal. 7(7), 43-50.

Korkmaz, M., 2004. Determination of optimum fire observation points using set covering model. Turkish Journal of Forestry, 1, $37-49$. 